\title{
EFFECTS OF MESENCHYMAL STEM CELL TRANSPLANTATION INTO ISCHEMIC BILE DUCT INJURY TISSUES OF RATS ON THE EXPRESSION OF VASCULAR ENDOTHELIAL CELL PHENOTYPE AND THE INCREASE OF VASCULAR DENSITY
}

\author{
Weihua Jiang, Li Lu \\ Jiangsu Province Hospital of TCM, Nanjing 210029, Jiangsu Province, P. R. China \\ ${ }^{*}$ Corresponding author, E-mail: Iulijphtcm@yahoo.com
}

\begin{abstract}
We aimed to evaluate the effects of mesenchymal stem cell (MSC) transplantation into the ischemic bile duct injury tissues of rats on the expression of vascular endothelial cell phenotype and the increase of vascular density. The bone marrow of male Wistar rats aged 2-4 weeks was sampled to culture MSCs by the direct adhesion method. Forty-six female rats were randomly divided into a transplantation group (group A) and a non-transplantation group (group B). Group A was transplanted with MSCs $\left(1 \times 10^{6} \mathrm{cells} / \mathrm{site}\right.$, a total of 8 sites $)$ into ischemic biliary lesion. After 21 days, the bile ducts with lesions were removed. The transplanted MSCs were tracked by a combination of in situ hybridization staining of sex-determining region $Y$ gene with CD34 immunohistochemical staining (double labeling). Microvascular and vascular endothelial growth factors were labeled by immunohistochemical staining to calculate microvascular density (MVD). After 21 days of injection, double labeling revealed that a small portion of Y-chromosome positive cells in group A (brown cell nucleus) had CD34 antigen phenotype (bluish violet). MVD of group A ((63 \pm 18$) / H P)$ was higher than that of group $B((53 \pm 14) / H P)$, and the vascular endothelial growth factor (VEGF) expressions of the two groups were significantly different $(P<0.05)$. The formation of vascular endothelial cells after MSC transplantation improved the blood supply of bile duct by secreting VEGF.
\end{abstract}

Key words: mesenchymal stem cell; transplantation; in situ hybridization; immunohistochemistry; bile duct injury

\section{Introduction}

Bone marrow-derived stem cells have been used clinically to promote myocardial regeneration and angiogenesis (1). However, how to select ideal cell subsets for cell therapy is still controversial owing to different compositions of cell populations (2). Versatile mesenchymal stem cells (MSCs) found in bone marrow can differentiate into neurons, skeletal muscle cells and vascular endothelial cells (3). Therefore, neovascularization can be induced by injecting MSCs into infarcted myocardium $(4,5)$.

Received:27 March 2019

Accepted for publication: 14 October 2019
On the other hand, ischemic biliary lesion is a tricky complication in hepatobiliary surgeries, which cannot be satisfactorily treated with repeated intervention or surgical repair hitherto. Zhao et al. reported the preventive effects of transplanting bone marrow mononuclear cells into a mouse model of bile duct ischemia on their ischemic stenosis (6). Considering that falsepositive results may be obtained by tracking the cells with 5-bromo-2-deoxyuridine (BrdU), a combination of SRY (sex-determining region Y gene) DNA in situ hybridization staining with CD34 immunohistochemical staining (double labeling) was used herein to determine whether transplanted MSCs could differentiate into 
vascular endothelial cells. Moreover, vascular endothelial growth factor (VEGF) expression and microvascular density (MVD) were detected by immunohistochemical staining. The experimental results prove that MSC transplantation can prevent stenosis induced by ischemic bile duct injuries.

\section{Materials and methods}

\section{Experimental animals}

This study has been approved by the animal experiment ethics committee of our hospital, and great efforts have been made to minimize the suffering. Forty-six healthy and clean female Wistar rats aged 8-12 weeks and weighing 200-300 $\mathrm{g}$ were provided by the Institute of Experimental Animals, Chinese Academy of Medical Sciences (Animal Certificate No. SCXK (Beijing) 20170006). The rats were randomly divided into group A (transplantation group) and group B (nontransplantation group).

\section{Apparatus and reagents}

Microscopic artery clamp, ophthalmic scissor, small vessel forcep and microscopic artery forcep were purchased from Shanghai Medical Instruments (Group) Ltd., Corp. Surgical Instruments Factory (China). SRY DNA in situ hybridization staining system was obtained from Wuhan Boster Biological Engineering Co., Ltd. (China). Rabbit anti-rat CD34 antigenantibody IgG and rabbit anti-rat VEGF antigenantibody IgG were provided by Beijing Boaosen Biological Engineering Co., Ltd. (China). Peroxidase-conjugated streptavidin (SP) staining kit, concentrated dimethyl-benzidine (DAB), nitroblue tetrazolium $(400 \mathrm{\mu g} / \mathrm{ml})$ and 5-bromo4-chloro-3-indolephosphate (BCIP/NBT) color development kit were purchased from Fuzhou Maxim Biotechnology Co., Ltd. (China).

\section{Separation, culture and identification of MSCs}

MSCs were cultured and harvested by using the method of Wexler et al. (7). The femurs and tibias of six-week-old male albino Wistar rats were carefully dissected away from attached soft tissues, the bone ends were cut, and the bone marrow was aseptically flushed with Dulbecco's modified Eagle's medium (DMEM, Gibco, UK). The mononuclear fraction was isolated by density gradient centrifugation at $435 \times \mathrm{g}$ for $30 \mathrm{~min}$ at room temperature and seeded at a density of $1 \times 10^{6}$ cells $/ \mathrm{cm}^{2}$ into T75 cell culture flasks (Nunc, Austria). The cells were plated in DMEM-low glucose (Gibco, UK) supplemented with $10 \%$ fetal calf serum (Sigma, Germany) and 1\% penicillinstreptomycin (Gibco, UK), and cultured at $37^{\circ} \mathrm{C}$ in a $5 \% \mathrm{CO}_{2}$ atmosphere. After three days, a small number of adherent cells grew into a visible symmetric colony, and non-adherent cells were removed when the medium was refreshed every three days. The remaining purified MSCs were further amplified in a culture flask. The cells were grown to confluence, harvested by incubation with $0.25 \%$ trypsin/1 mM EDTA (Gibco, UK), centrifuged at $1200 \mathrm{rpm}$ for $5 \mathrm{~min}$, and subcultured at a 1:3 split ratio in new culture flasks. After confluence was reached for the second time (after eight days), the harvested cells were defined as passage one, and the replated cells were cultured and serially subcultured until passage four. The fourth-passage cells were then transplanted. Cell concentration was maintained at $4-10 \times 10^{7} / \mathrm{L}$, and viability was determined as $>80 \%$ by trypan blue staining.

\section{Animal treatment}

Two rat groups were anesthetized by the intraperitoneal injection of pentobarbital $(20 \mathrm{mg} /$ $\mathrm{kg}$ ), and an extrahepatic biliary ischemia model was established by clamping the extrahepatic bile duct (6), leading to an irreversible ischemic injury. The rectal temperature was maintained at $(37.0 \pm 0.5)^{\circ} \mathrm{C}$ by a heat lamp. The rats were intramuscularly injected with 500,000 units of penicillin during operation. Afterwards, they were housed in standard conditions and fed with free access to food and water.

Group A: The rats were not fed with food or water $6 \mathrm{~h}$ and $3 \mathrm{~h}$ before operation. Then they were intraperitoneally injected with pentobarbital $(20 \mathrm{mg} / \mathrm{kg})$ for anesthesia and fixed on an operating table, the abdomens of which were disinfected with iodophor. Under sterile conditions, the extrahepatic bile duct was exposed (incision was 
made in the middle of the abdomen: $3 \mathrm{~cm}$ ). After being rinsed by normal saline, the isolated great omentum (about $0.4 \mathrm{~cm} \times 0.4 \mathrm{~cm} \times 0.6 \mathrm{~cm}$ ) was intermittently stitched by $5-0$ silk thread. Then MSC suspension was uniformly injected into the greater omentum at 8 sites by a $1 \mathrm{ml}$ syringe (each site: $25 \mu 1,1 \times 10^{6}$ cells). The abdominal cavity was sutured with 3-0 silk thread. Group B was treated similarly but injected with $25 \mu$ of PBS instead into the greater omentum. No rats died of anesthesia or improper operations, or received immunosuppression therapy.

\section{Sample collection}

Twenty-one days after surgery, the tissues wrapping the greater omentum and those near the bile duct were collected, rinsed with normal saline, fixed in $4 \%$ paraformaldehyde and prepared into paraffin-embedded sections.

\section{Immunohistochemical staining}

The immunohistochemical SP method was utilized for VEGF and MVD staining. A slice known positive for breast cancer (Beijing Biosynthesis Biotechnology Co., Ltd., China) was used as the positive control, and two rat biliary slices were employed as the negative control, with primary antibody replaced by PBS. The detection was performed according to kit's introductions.

Assessment of immunohistochemical staining results

VEGF staining results were determined by the semiquantitative scoring method (8). Four representative high-power fields were selected, with 100 cells counted for each field. The slices were scored based on the degree of staining and percentage of stained cells: 0 point for unstained, 1 point for light yellow, 2 points for brown, 3 points for dark brown. The percentage of stained cells to counted cells was scored as 0 to 3 points: 0 point for $\leq 5 \%, 1$ point for $6 \%-25 \%, 2$ points for $26 \%$ $50 \%$, and 3 points for $\geq 51 \%$. The score of staining degree and that of percentage of stained cells for each slice were added as the final score: 0 point for negative (-), 1 to 2 points for weakly positive $(+), 3$ to 4 points for positive $(++)$, and 5 to 6 points for strongly positive $(+++)$.

\section{Microvascular measurement}

Microvessels were counted according to the Weidner's method (9). If single endothelial cells stained bluish violet existed in clusters and were separated from adjacent blood vessels, parenchymal cells and mesenchymal components, a blood vessel count was determined. There is no need to determine whether they are blood vessels by the appearance of erythrocytes, or by the complete lumen. The complete slice was observed at low magnification to find three regions with highdensity blood vessels for counting. The average of microvascular numbers in the three regions was MVD of this sample. Immunohistochemical staining, result determination and MVD calculation were completed by two pathologists blinded to this study.

\section{In situ hybridization and immunohisto- chemical double-labeled staining}

The transformation of transplanted cells into vascular endothelial cells was verified by in situ hybridization staining of genes in the sex-determining region of $\mathrm{Y}$ chromosome in combination with immunohistochemical CD34 antigen staining. After transplantation, MSCs that did not express CD34 had no phenotypic changes, indicating the transformation into vascular endothelial cells.

Detailed experimental steps: 1) Paraffin sections were rehydrated with gradient concentrations of ethanol solutions; 2) the permeability of tissues and cells was elevated for $10 \mathrm{~min}$ at room temperature, allowing the probe to penetrate the cell membrane rapidly; 3) digestion working solution was dropwise added to cover the tissue surface for $10 \sim 30 \mathrm{~min}$ at $37^{\circ} \mathrm{C}$; 4) the sample was incubated in $0.1 \mathrm{~mol} / \mathrm{L}$ TBS for $15 \sim 20 \mathrm{~min}$ at $95^{\circ} \mathrm{C}$, washed with $0.1 \mathrm{~mol} / \mathrm{L}$ cold TBS 3 times (5 min each time), placed in $50 \%$ formamide on ice bath for $20 \mathrm{~min}$, and washed 3 times with 0.1 mol/L TBS (5 min each time); 5) then the tissue sample was dropwise added pre-hybridization working solution and incubated in a wet box for $1 \mathrm{~h}$ at $37^{\circ} \mathrm{C}$; 6) it was washed after pre-hybridization; 7) it was dropwise added hybridization working solution and incubated in a wet box for $4 \mathrm{~h}$ at $37^{\circ} \mathrm{C}$; 8) it was washed again; 9) the tissue sample was dropwise added a mixture of 
peroxidase-conjugated avidin working solution (1:800 diluted) and rabbit anti-rat CD34 antibody $(1: 150$ diluted $) ; 10)$ then it was dropwise added biotin-labeled goat anti-rabbit IgG working solution, incubated for $20 \mathrm{~min}$ at $37^{\circ} \mathrm{C}$ and washed 3 times with PBS; 11) it was thereafter dropwise added alkaline phosphatase-labeled streptavidin working solution, incubated for $20 \mathrm{~min}$ at $37^{\circ} \mathrm{C}$ and washed 3 times with PBS; 12) after DAB color development, it was washed 3 times with PBS and twice with TSM1; 13) color development was conducted with a mixture of NBT $(400 \mu \mathrm{g} / \mathrm{ml})$ and 5-bromine-4-chlorine-3-indole phosphate (200 $\mathrm{\mu g} / \mathrm{ml}$ ) for $0.5 \sim 3 \mathrm{~h}$ in dark; 14 ) the reaction was stopped by adding $20 \mathrm{mmol} / \mathrm{L}$ EDTA; 15) nuclear counterstaining, dehydration and mounting with resin were finally carried out.

\section{Statistical analysis}

The categorical data were represented as $\bar{X} \pm$ $\mathrm{S}$. The categorical data and numerical data were subjected to the t test and rank-sum test using SPSS19.0 software respectively. $\mathrm{P}<0.05$ was considered statistically significant.

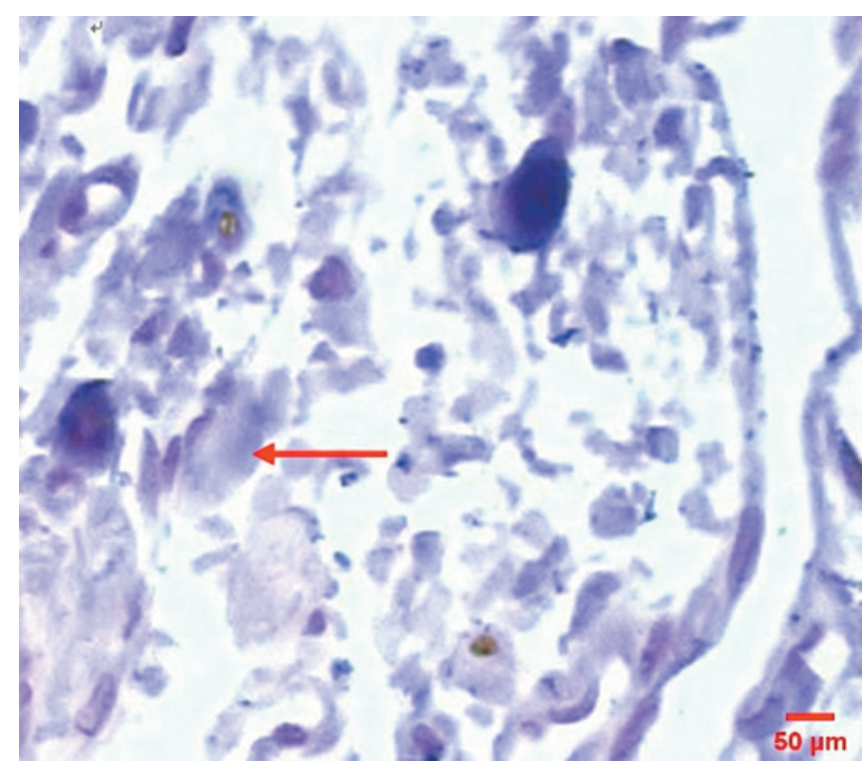

Figure 1: MSC phenotype change and CD34 expression in group A. MSCs were subjected to in situ hybridization staining and CD34 immunohistochemical staining (double labeling). Scale bar: $50 \mu \mathrm{m}$; magnification: 200×. CD34 was expressed (bluish violet by immunohistochemical staining; red arrow) in a small portion of Y-chromosome positive cells (brown nucleus) in the vascularized area

\section{Results}

\section{Transformation of MSCs into vascular endothelial cells}

In the postoperative feeding period, 2 rats in group A and 3 in group B died, respectively. Representative photographs of tissue samples were taken for three different rats from each group. The brown nucleus and unstained cytoplasm by in situ hybridization staining revealed that the cell contained Y chromosome and was indeed transplanted cell. The hyacinthine cell membrane and unstained nucleus by immunohistochemical staining showed that the cell membrane expressed CD34, verifying the nature of vascular endothelial cell. The bluish violet membrane of double-labeled cell and brown nucleus suggested that the transplanted cell was transformed into vascular endothelial cell. After 21 days of injection into ischemic biliary lesion, double labeling revealed that a small portion of Y-chromosome positive cells (brown nucleus) expressed CD34 (bluish violet in immunohistochemical staining) phenotype in the vascularized area of group

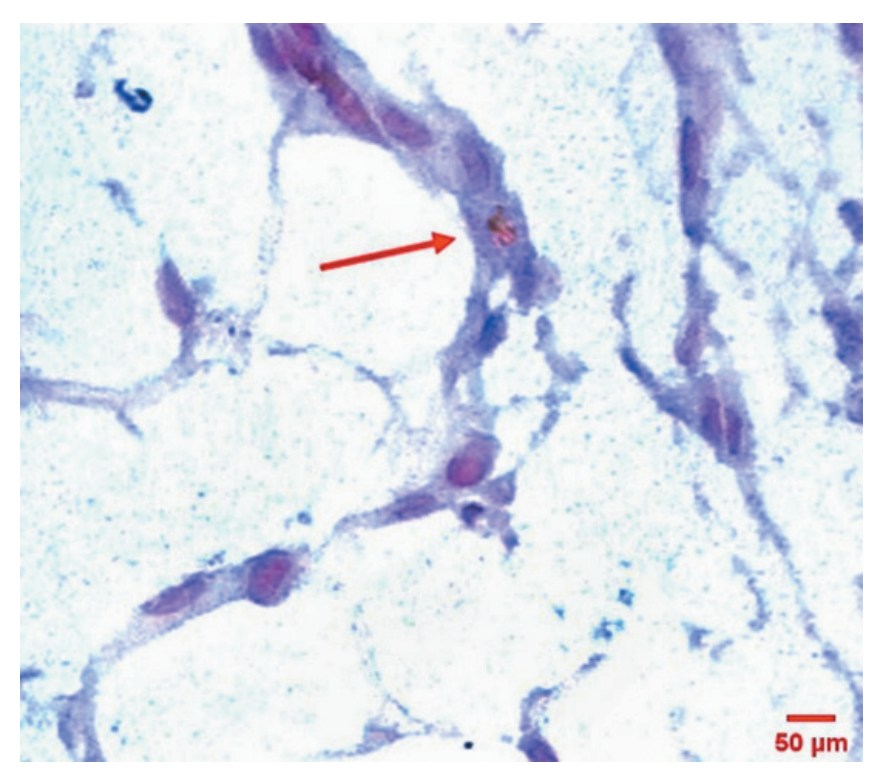

Figure 2: Transformation from MSC into adipose cell in group A. MSCs were subjected to in situ hybridization staining and CD34 immunohistochemical staining (double labeling). Scale bar:50 um; magnification: 200×. CD34 was expressed (bluish violet by immunohistochemical staining; red arrow) in adipose cells 


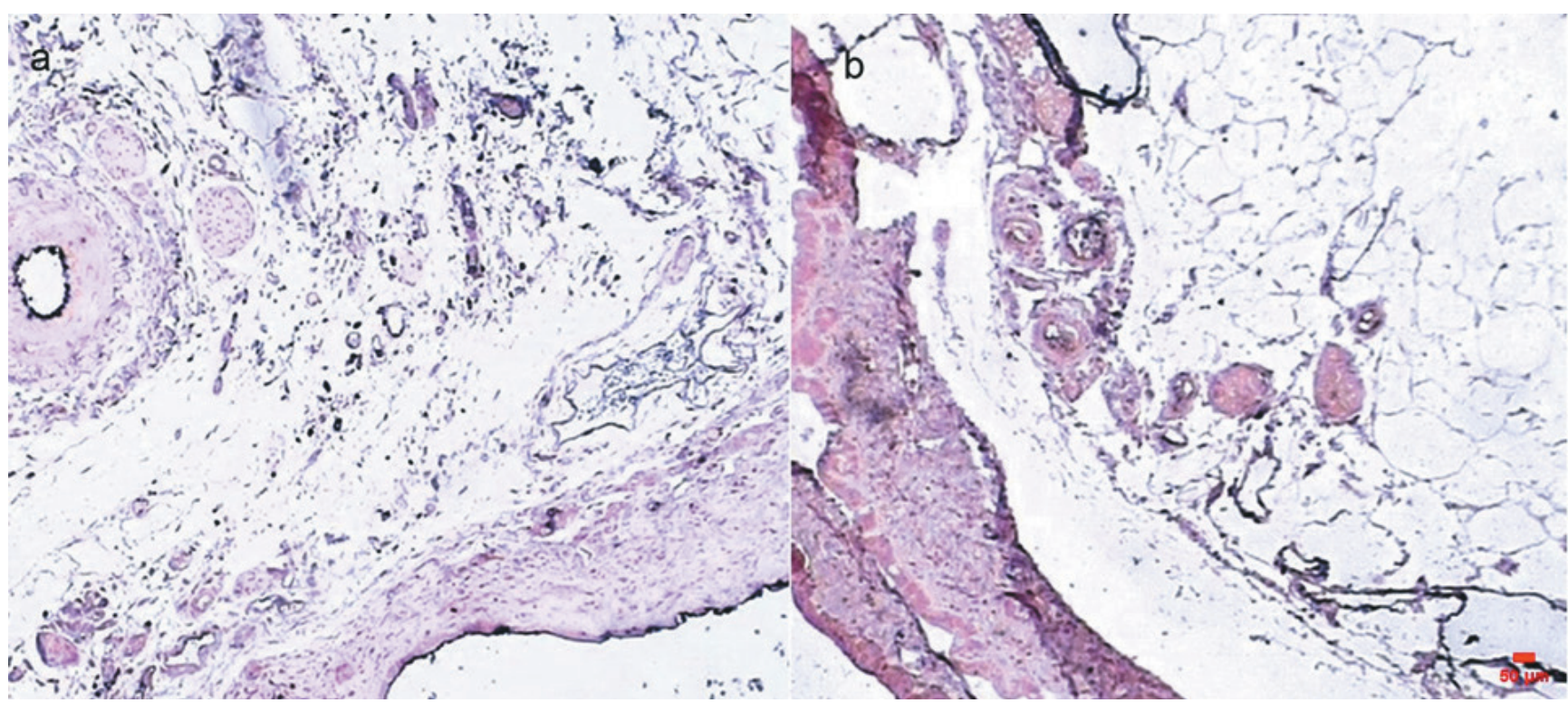

Figure 3: Vascular staining results of (a) group A and (b) group B. MVD of group A was higher than that of group B. Scale bar: $50 \mu \mathrm{m}$; magnification: $10 \times$

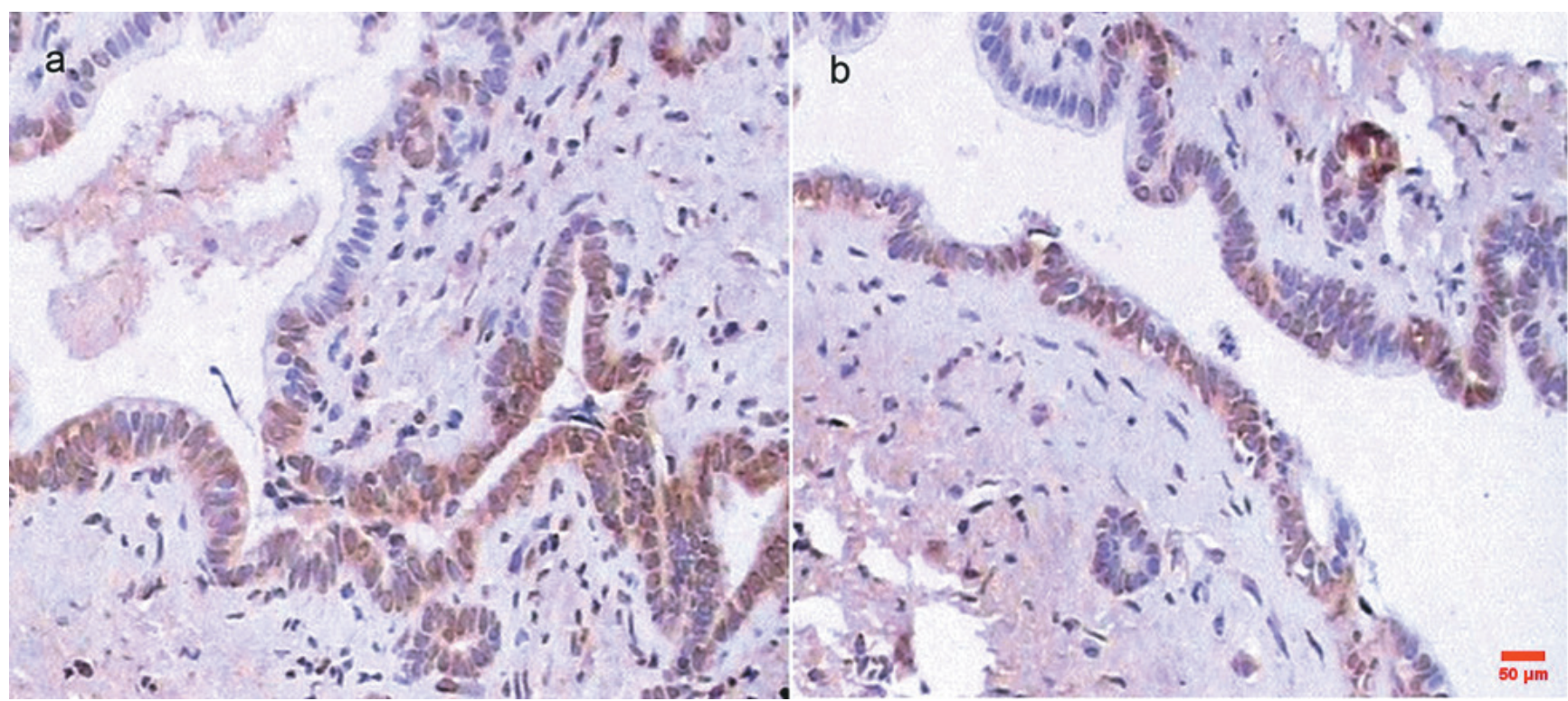

Figure 4: VEGF expressions of (a) group A and (b) group B. VEGF expression in group A was much higher than that of group B. Scale bar: $50 \mu \mathrm{m}$; magnification: $100 \times$

Table 1: VEGF expressions of two groups

\begin{tabular}{|c|c|c|c|c|c|}
\hline \multirow{2}{*}{ Group } & \multirow{2}{*}{ Case number } & \multicolumn{4}{|c|}{ VEGF expression scoring } \\
\hline & & - & + & ++ & +++ \\
\hline A & 21 & 0 & 2 & 7 & 12 \\
\hline B & 20 & 0 & 3 & 10 & 7 \\
\hline
\end{tabular}


A (Figure 1; scale bar: $50 \mu \mathrm{m}$; magnification: 200x). Although transplanted cell undergoing canalization was absent, Y-chromosome positive cells were found in adipose tissue (Figure 2; scale bar: $50 \mu \mathrm{m}$; magnification: $200 \times$ ), indicating that MSCs turned into adipose cells.

\section{MSCs promoted angiogenesis by increas- ing VEGF expression}

After 21 days of injection into ischemic biliary lesion, vascular staining showed that MVD of group A was higher than that of group B (Figure 3; scale bar: $50 \mu \mathrm{m}$; magnification: $10 \times)$, which were calculated as (63.3 \pm 17.6$) / \mathrm{HP}$ and (53.2 \pm 13.8$) /$ HP, respectively $(\mathrm{P}<0.05)$. Moreover, cytoplasmic staining exhibited that the VEGF expression in group A was much higher, mostly in the MSC transplantation area (Figure 4; scale bar: $50 \mu \mathrm{m}$; magnification: 100 $\times$ ). Table 1 also shows that the VEGF expression in group A significantly exceeds that in group $\mathrm{B}(\mathrm{P}<0.05)$.

\section{Discussion}

MSCs are pluripotent stem cells originating from the early mesoderm and ectoderm, with high heterogeneity and multipotential differentiation capacity. MSCs can express mRNAs of multilineage cells, such as chondrocytes, adipocytes, neurons, myocytes and endothelial cells. Endothelial cells, which exist in the mesoderm, are first differentiated during embryonic development, so MSCs may differentiate into endothelial cells. Kinnaird et al. further proved that bone marrowderived stem cells secreted vascular cytokines to stimulate the proliferation and migration of endothelial and smooth muscle cells via paracrine signaling, finally promoting arteriogenesis (10). After marrow stromal cell-derived conditioned medium was locally injected, the limb damage and tissue atrophy in a murine model of hindlimb ischemia were relieved.

MSCs may retain some characteristics of stem cells, being capable of differentiating into the structural components of vascular wall in vitro and promoting the angiogenesis of ischemic lower limbs in vivo (11). Iwase et al. compared the roles of MSCs and myelomonocytes in the angiogenesis of ischemic lower limbs, and found that the angiogenesis of both cells increased, but that of the former was more obvious (12). MSC has stronger viability in the ischemic environment than that of myelomonocyte, which can differentiate into either endothelial cell or vascular smooth muscle cell. The mononuclear cell subset of bone marrow consists of a variety of cells, such as MSCs, hematopoietic cells, endothelial cells and committed cell lines (e.g. NK cells, T lymphocytes and B lymphocytes). Theoretically, the ideal cell type for cell therapy should lack commitment, which can facilitate angiogenesis and trigger vasculogenesis. Collectively, MSCs have both high plasticity and viability (13).

After intramyocardial injection with $1 \mathrm{ml}$ of $5 \times 10^{7} / \mathrm{ml}$ MSCs, labeled MSCs appear in infarcted areas (14), and the cardiac function is not enhanced with increasing number of transplanted cells. In this study, $4 \times 10^{7} / \mathrm{ml}$ MSCs were injected. Similarly, Hashemi et al. used $2.5 \times 10^{7}$ cells $/ \mathrm{ml}$ and found uninjured MSCs in infarcted areas (15).

We herein evaluated the effects of MSCs on the improvement of blood supply for impaired biliary tract after being transplanted to ischemic biliary lesion. Angiogenesis refers to the growth of new blood capillary vessels originating from existing ones and post-capillary venule. Angiogenesis is an extremely complicated process, generally including vascular endothelial matrix degradation, migration and proliferation of endothelial cells, as well as formation of vascular ring and new basilar membrane. Therefore, the enhancing effects of MSCs on the blood supply of biliary tract can be directly assessed by detecting the formation of blood capillary vessels, using markers labeling the vascular endothelium, i.e. F8RA/Vwf, CD31 and CD34. CD34 is a transmembrane glycoprotein with a molecular weight of $110 \mathrm{kD}$, which is expressed in white blood cells, endothelial cells and stem cells. It has the strongest expression in capillary endothelial cells, followed by the artery, vein, arteriole and venule. CD34 ${ }^{+}$transplanted cells verify the transformation of MSCs into vascular endothelial cells. Thus, CD34 was selected as the marker in this study. The combination of in situ hybridization staining and immunohistochemical double labeling showed that MVD of group A was higher than that of group B, and a small portion of Y-chromosome positive cells (brown nucleus) expressed CD34 (bluish violet in immunohistochemical staining) phenotype in the vascularized area of group A after 21 days of MSC injection. Given that female rats were recipients, 
the Y-chromosome positive cells must originate from the transplanted cells of male donor rats. MSCs themselves do not express CD34. Accordingly, the double-labeled positive cells demonstrated that cell phenotype changed after MSC transplantation and turned into vascular endothelial cells. Although no transplanted cells underwent canalization, they expressed CD34 in adipose tissue, confirming their survival and growth around the biliary tract. Group A had significantly higher VEGF expression and MVD than those of group $\mathrm{B}(\mathrm{P}<0.05)$. Thus, MSCs survived after transplantation and promoted angiogenesis by increasing VEGF expression, being consistent with previous literatures $(16,17)$. Previous studies on the transformation of MSCs into vascular endothelial cells have focused on the myocardium and skeletal muscle. Comparatively speaking, the biliary tract has fewer tissues around, and cells after transplantation lack a living environment that they can rely on. Hence, we performed MSC transplantation after using the greater omentum to wrap the biliary tract. After transplantation, MSCs promoted angiogenesis to improve the blood supply for biliary tract by transforming into vascular endothelial cells and secreting angiogenic factor. Besides, another significance of this study is that immunosuppressive therapy is not required for allogenic MSC transplantation. MSCs from human beings have low immunogenicity (18). Moreover, allogenic MSCs can be transplanted into nonmyocardial tissues lacking immunodepression on a long-term basis (19). Therefore, allogenic MSCs are potentially superior to autologous hematopoietic stem cells in clinical practice. For example, during liver transplantation surgery in the future, MSCs can be injected around the biliary tract owing to the large possibility of ischemic stenosis.

In conclusion, rat ischemic biliary injury can be safely and effectively treated through local transplantation of MSCs. MSCs improved biliary blood supply by differentiating into vascular endothelial cells, secreting angiogenic factor and increasing blood vessels. MSC transplantation may be an alternative method for treating ischemic diseases.

\section{Acknowledgments}

This study was not financially supported. The authors declare no conflict of interest.

\section{References}

1. Rasmussen JG, Frøbert O, Holst-Hansen $\mathrm{C}$, et al. Comparison of human adipose-derived stem cells and bone marrow-derived stem cells in a myocardial infarction model. Cell Transplant 2014; 23: 195-206.

2. Turtle CJ, Hanafi LA, Berger C, et al. CD19 CAR-T cells of defined CD4+: CD8+ composition in adult B cell ALL patients. J Clin Invest 2016; 126: 2123-38.

3. Ullah I, Subbarao RB, Rho GJ. Human mesenchymal stem cells-current trends and future prospective. Biosci Rep 2015; 35: e00191. doi: 10.1042/BSR20150025

4. Rogers TB, Pati S, Gaa S, et al. Mesenchymal stem cells stimulate protective genetic reprogramming of injured cardiac ventricular myocytes. J Mol Cell Cardiol 2011; 50: 346-56.

5. Teng X, Chen L, Chen W, Yang J, Yang Z, Shen $Z$. Mesenchymal stem cell-derived exosomes improve the microenvironment of infarcted myocardium contributing to angiogenesis and anti-inflammation. Cell Physiol Biochem 2015; 37: 2415-24.

6. Zhao DF, Chen DZ, Lv JS, Lang R, Jin ZK, Qing H. Establishment of an animal model of biliary ischemic stenosis with clamping in mice. Transplant Proc 2008; 40: 1303-5.

7. Wexler SA, Donaldson C, Denning-Kendall P, Rice C, Bradley B, Hows JM. Adult bone marrow is a rich source of human mesenchymal 'stem' cells but umbilical cord and mobilized adult blood are not. Br J Haematol 2003; 121: 368-74.

8. Song SH, Jeong IG, You D, et al. VEGF/ VEGFR2 and PDGF-B/PDGFR- $\beta$ expression in non-metastatic renal cell carcinoma: a retrospective study in 1,091 consecutive patients. Int J Clin Exp Pathol 2014; 7: 7681-9.

9. Weidner N. Current pathologic methods for measuring intratumoral microvessel density within breast carcinoma and other solid tumors. Breast Cancer Res Treat 1995; 36: 169-80.

10. Kinnaird T, Stabile E, Burnett MS, et al. Marrow-derived stromal cells express genes encoding a broad spectrum of arteriogenic cytokines 
and promote in vitro and in vivo arteriogenesis through paracrine mechanisms. Circ Res 2004; 94: 678-85.

11. Cao X, Wu X, Frassica D, et al. Irradiation induces bone injury by damaging bone marrow microenvironment for stem cells. Proc Natl Acad Sci U S A 2011; 108: 1609-14.

12. Iwase T, Nagaya N, Fujii T, et al. Comparison of angiogenic potency between mesenchymal stem cells and mononuclear cells in a rat model of hindlimb ischemia. Cardiovasc Res 2005; 66: 543-51.

13. Barachini S, Danti S, Pacini S, et al. Plasticity of human dental pulp stromal cells with bioengineering platforms: a versatile tool for regenerative medicine. Micron 2014; 67: 155-68.

14. Khan I, Ali A, Akhter MA, et al. Preconditioning of mesenchymal stem cells with 2, 4-dinitrophenol improves cardiac function in infarcted rats. Life Sci 2016; 162: 60-9.

15. Hashemi SM, Ghods S, Kolodgie FD, et al. A placebo controlled, dose-ranging, safety study of allogenic mesenchymal stem cells injected by endomyocardial delivery after an acute myocardial infarction. Eur Heart J 2008; 29: 251-9.

16. Yang J, Gao F, Zhang Y, Liu Y, Zhang D. Buyang Huanwu Decoction (BYHWD) enhances angiogenic effect of mesenchymal stem cell by upregulating VEGF expression after focal cerebral ischemia. J Mol Neurosci 2015; 56: 898-906.

17. Calio ML, Marinho DS, Ko G, et al. Transplantation of BM-MScs promotes angiogenesis and decreases superoxide levels in the brain of hypertensive rats: relevance for homologous transplantation as stroke therapy. Free Radical Biol Med 2018; 128: S124.

18. Lee M, Jeong SY, Ha J, et al. Low immunogenicity of allogeneic human umbilical cord blood-derived mesenchymal stem cells in vitro and in vivo. Biochem Biophys Res Commun 2014; 446: 983-9.

19. Klinker MW, Marklein RA, Lo Surdo JL, Wei $\mathrm{CH}$, Bauer SR. Morphological features of IFN- $\gamma$-stimulated mesenchymal stromal cells predict overall immunosuppressive capacity. Proc Natl Acad Sci U S A 2017; 114: E2598-607.

\title{
UČINKI TRANSPLANTACIJE MEZENHIMALNIH MATIČNIH CELIC V ISHEMIJSKO TKIVNO POŠKODBO ŽOLČNIH KANALOV NA IZRAŽANJE ŽILNEGA ENDOTELIJSKEGA FENOTIPA CELIC IN POVEČANJE CELIČNE GOSTOTE
}

\author{
W. Jiang, L. Lu
}

Povzetek: V študiji smo želeli oceniti učinke presaditve mezenhimskih matičnih celic (MSC) vishemična tkiva poškodovanih žolčnih kanalov pri podganah na izražanje fenotipa žilnih endotelijskih celic in na žilno gostoto. Celice kostnega mozga podganjih samcev seva Wistar, starih 2 - 4 tedne smo gojili v celični kulturi v ustreznih gojiščih. Šestinštirideset samic podgan je bilo naključno razdeljenih v presaditveno skupino (skupina A) in ne-presaditveno skupino (skupina B). Skupini A smo presadili MSC $\left(1 \times 10^{6}\right.$ celic/mesto, skupaj 8 mest) v ishemično poškodbo žolčnih kanalov. Po 21 dneh so bili poškodovani žolčni kanali odvzeti za histološke preiskave. Presajene MSC so bile spremljane s kombinacijo dveh metod - hibridizacije in situ, s katero smo označili gen Y za določanje spola, ter z imunohistokemičnim barvanjem proti beljakvoini CD34 (dvojno označevanje). Mikrovaskularni in vaskularni endotelni rastni faktorji so bili označeni z imunohistokemičnim barvanjem, na podlagi katerega smo izračunali mikrovaskularno gostoto (MVD). Enaindvajset dni po injiciranju je dvojno označevanje pokazalo, da je majhen del celic s kromosomov Y (presajenih celic) v skupini A izražal antigen CD34. MVD skupine A (63 \pm 18 )/HP) je bil večji od MVD v skupini B ((53 \pm 14$) / H P)$ in izražanje žilnih endotelnih rastnih faktorjev (VEGF) se je statistično značilno razlikovalo med skupinama $(P<0,05)$. Tvorba žilnih endotelnih celic po presaditvi MSC je izboljšala preskrbo žolčnih kanalov s krvjo preko izločanja VEGF.

Ključne besede: mezenhimske matične celice; presaditev; hibridizacija in situ; imunohistokemija; poškodbažolčnih kanalov 